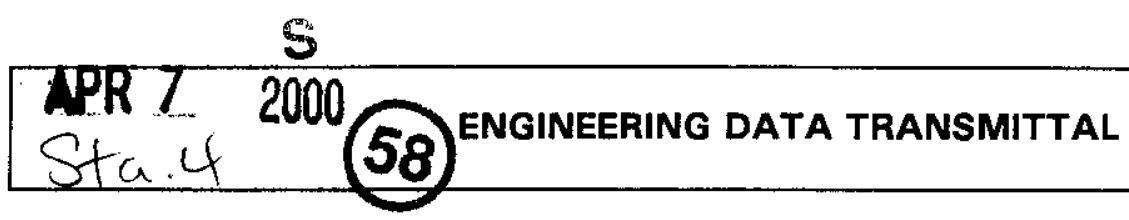

\begin{tabular}{|c|c|c|}
\hline $\begin{array}{l}\text { 2. To: (Receiving organization) } \\
\text { Distribution }\end{array}$ & $\begin{array}{l}\text { 3. From: (originating Organization) } \\
\text { Characterization Engineering }\end{array}$ & $\begin{array}{r}\text { 4. Related EDT No.: } \\
\text { N/A } \\
\end{array}$ \\
\hline $\begin{array}{l}\text { 5. Proj./Prog./Dept./Div.: } \\
\text { Long Length Contaminated } \\
\text { Equipment Transport System }\end{array}$ & $\begin{array}{l}\text { 6. Design Authority/ Design Agent/Cog. } \\
\text { Engr.: } \\
\text { GP Janicek/DF Hicks }\end{array}$ & $\begin{array}{l}\text { 7. Purchase Order No.: } \\
\qquad N / A\end{array}$ \\
\hline \multirow{2}{*}{\multicolumn{2}{|c|}{$\begin{array}{l}\text { 8. Originator Remarks: } \\
\text { The attached Engineering Task Plan describes the management } \\
\text { strategy for preparing the LLCETS for deployment in RPP. } \\
\text { This plan also provides requirements for turnover of the } \\
\text { LLCETS to Characterization Project Operations, including a } \\
\text { Partial Acceptance for Beneficial Use (ABU). }\end{array}$}} & $\begin{array}{l}\text { 9. Equip./Component No.: } \\
\qquad \mathrm{N} / \mathrm{A}\end{array}$ \\
\hline & & 10. System/Bldg./Facility: \\
\hline \multirow{3}{*}{\multicolumn{2}{|c|}{$\begin{array}{l}\text { 11. Receiver Remarks: 11A. Design Baseline Document? [] Yes [X] No } \\
\text { Approval of the ETP is indicated by signature on this EDT. }\end{array}$}} & $\begin{array}{l}\text { 12. Major Assm. Dwg. No.: } \\
\mathrm{H}-2-827806\end{array}$ \\
\hline & & $\begin{array}{l}\text { 13. Permit/Permit Application No.: } \\
\text { N/A }\end{array}$ \\
\hline & & $\begin{array}{l}\text { 14. Required Response Date: } \\
\text { January 27, } 2000\end{array}$ \\
\hline
\end{tabular}

\begin{tabular}{|c|c|c|c|c|c|c|c|c|c|c|}
\hline 15. & \multicolumn{6}{|c|}{ DATA TRANSMITTED } & (F) & (G) & $(\mathrm{H})$ & (I) \\
\hline $\begin{array}{l}\text { (A) } \\
\text { Item } \\
\text { No. }\end{array}$ & \multicolumn{2}{|c|}{ (B) Document/Drawing No. } & $\begin{array}{l}\text { (c) } \\
\text { Sheet } \\
\text { No. }\end{array}$ & $\begin{array}{l}\text { (D) } \\
\text { Rev. } \\
\text { No. }\end{array}$ & \multicolumn{2}{|c|}{$\begin{array}{l}\text { (E) Title or Description of } \\
\text { Data Transmitted }\end{array}$} & $\begin{array}{l}\text { Approva } \\
\quad \text { L } \\
\text { Desig- } \\
\text { nator }\end{array}$ & $\begin{array}{l}\text { Reaso } \\
\text { n for } \\
\text { Trans } \\
- \\
\text { mitta } \\
\text { i }\end{array}$ & $\begin{array}{c}\text { Origi } \\
- \\
\text { nator } \\
\text { Dispo } \\
\text { - } \\
\text { sitio } \\
\text { n }\end{array}$ & $\begin{array}{l}\text { Receiv } \\
- \\
\text { er } \\
\text { Dispo- } \\
\text { sition }\end{array}$ \\
\hline 1 & \multicolumn{2}{|l|}{ RPP-5684 } & - & 0 & \multicolumn{2}{|c|}{$\begin{array}{l}\text { ETP (ETN-98-0007) } \\
\text { Preparation of LLCETS } \\
\text { for Deployment }\end{array}$} & SQ & 1 & 1 & 1 \\
\hline \multicolumn{11}{|c|}{ KEY } \\
\hline \multicolumn{2}{|c|}{$\begin{array}{l}\text { Approval Designator } \\
\text { (F) }\end{array}$} & \multicolumn{4}{|c|}{ Reason for Transmittal (G) } & \multicolumn{5}{|c|}{ Disposition (H) \& (I) } \\
\hline \multicolumn{2}{|c|}{ (Ref: RPP-PRO-233) } & \multicolumn{4}{|c|}{$\begin{array}{l}\text { 1. Approval 4. Review } \\
\text { 2. Release 5. Post-Review } \\
\text { 3. Information6. Dist. (Receipt Acknow. } \\
\text { Required) }\end{array}$} & \multicolumn{5}{|c|}{$\begin{array}{ll}\text { 1. Approved } & \text { 4. Reviewed no/comment } \\
\text { 2. Approved w/comment } & 5 \text {. Reviewed w/comment } \\
\text { 3. Disapproved w/comment6. Receipt acknowledged }\end{array}$} \\
\hline
\end{tabular}

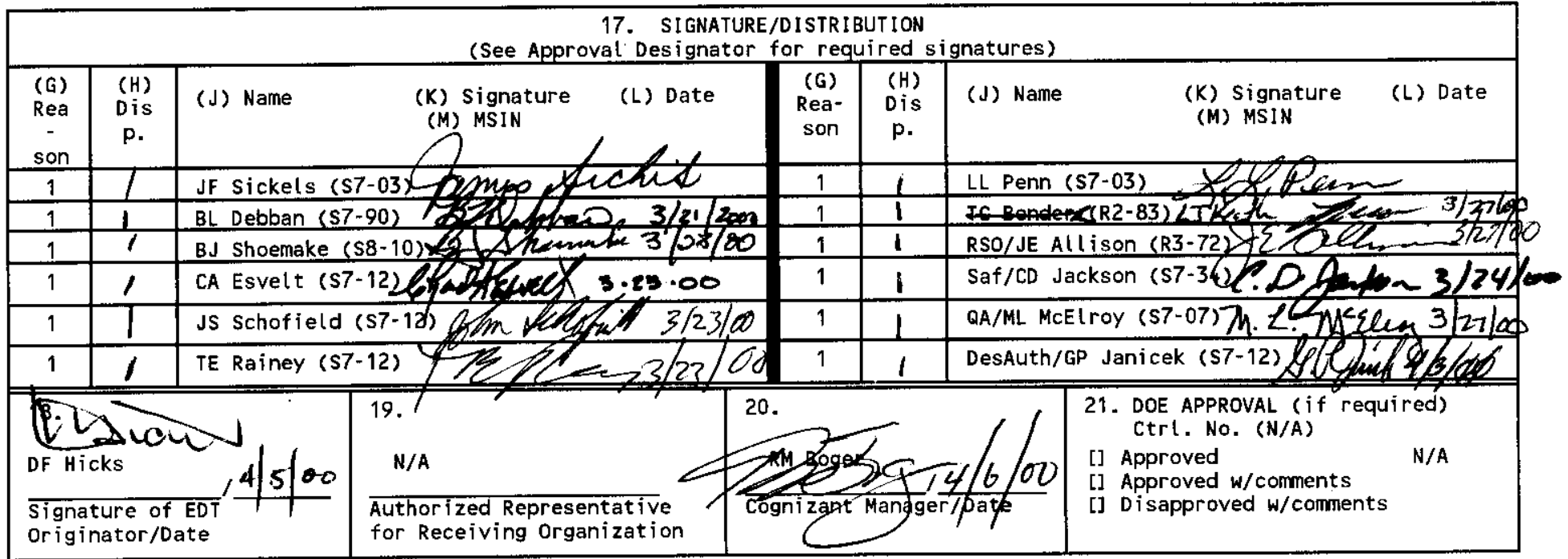


RPP-5684, Rev. 0

\section{ENGINEERING TASK PLAN}

(ETN-98-0007)

\section{Preparation of the Long Length Contaminated Equipment Transport System (LLCETS) for Deployment}

R. M. Boger

Prepared by CH2M-Hill Hanford Group, Richland, WA 99352

U.S. Department of Energy RPP Contract DE-AC06-99RL14047

$\begin{array}{llll}\text { EDT/ECN: } & 617987 & \text { UC: } & 721 \\ \text { Cost Center: } & 6 N 300 & \text { Charge Code: } & 110337 / \text { LMSI 4851, Re1. } 33 \\ \text { B\&R Code: } & \text { EW3120074 } & \text { Total Pages: } & 25\end{array}$

Key Words: LLCETS, LLCE, LLCERS, Long Length Contaminated Equipment, tilt trailer, receiver trailer, EPA Debris Rule, equipment removal, riser-mounted equipment.

Abstract: This task plan addresses the scope, schedule, and deliverables associated with preparation of the Long Length Contaminated Equipment Transport System for deployment in the Tank Farms.

TRADEMARK DISCLAIMER. Reference herein to any specific commercial product, process, or service by trade name, trademark, manufacturer, or otherwise, does not necessarily constitute or imply its endorsement, recommendation, or favoring by the United States Government or any agency thereof or its contractors or subcontractors.

Printed in the United States of America. To obtain copies of this document, contact: Document Control Services, P.O. Box 950, Mailstop H6-08, Richland WA 99352, Phone (509) 372-2420; Fax (509) 376-4989.
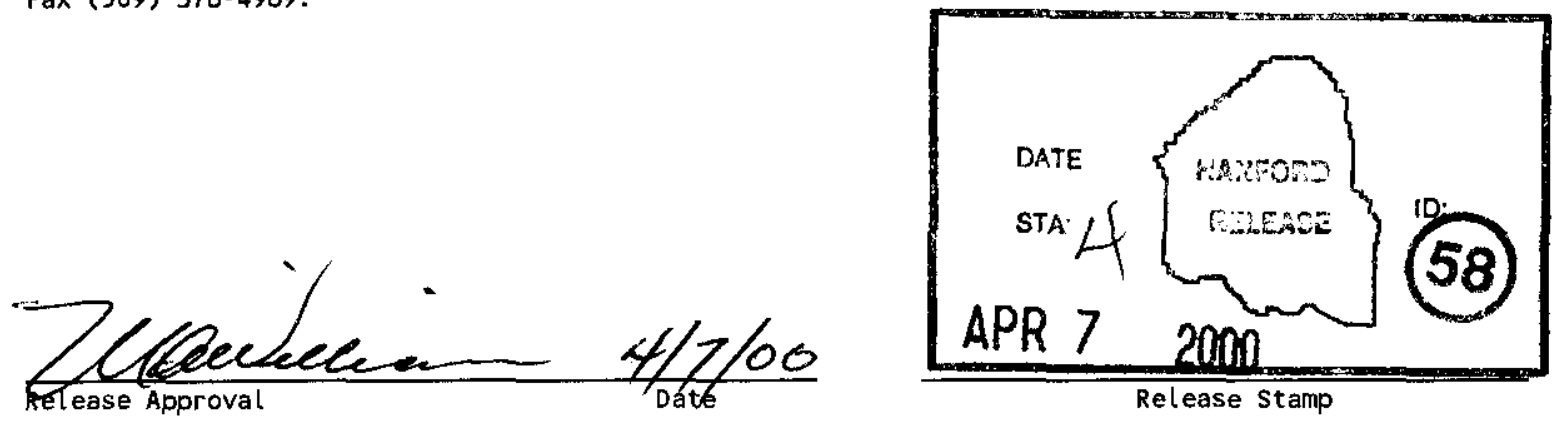


\section{RECORD OF REVISION}

(2) Title

ENGINEERING TASK PLAN (ETN-98-0007) - Preparation of the Long Length Contaminated Equipment Transport System (LLCETS) for Deployment

CHANGE CONTROL RECORD

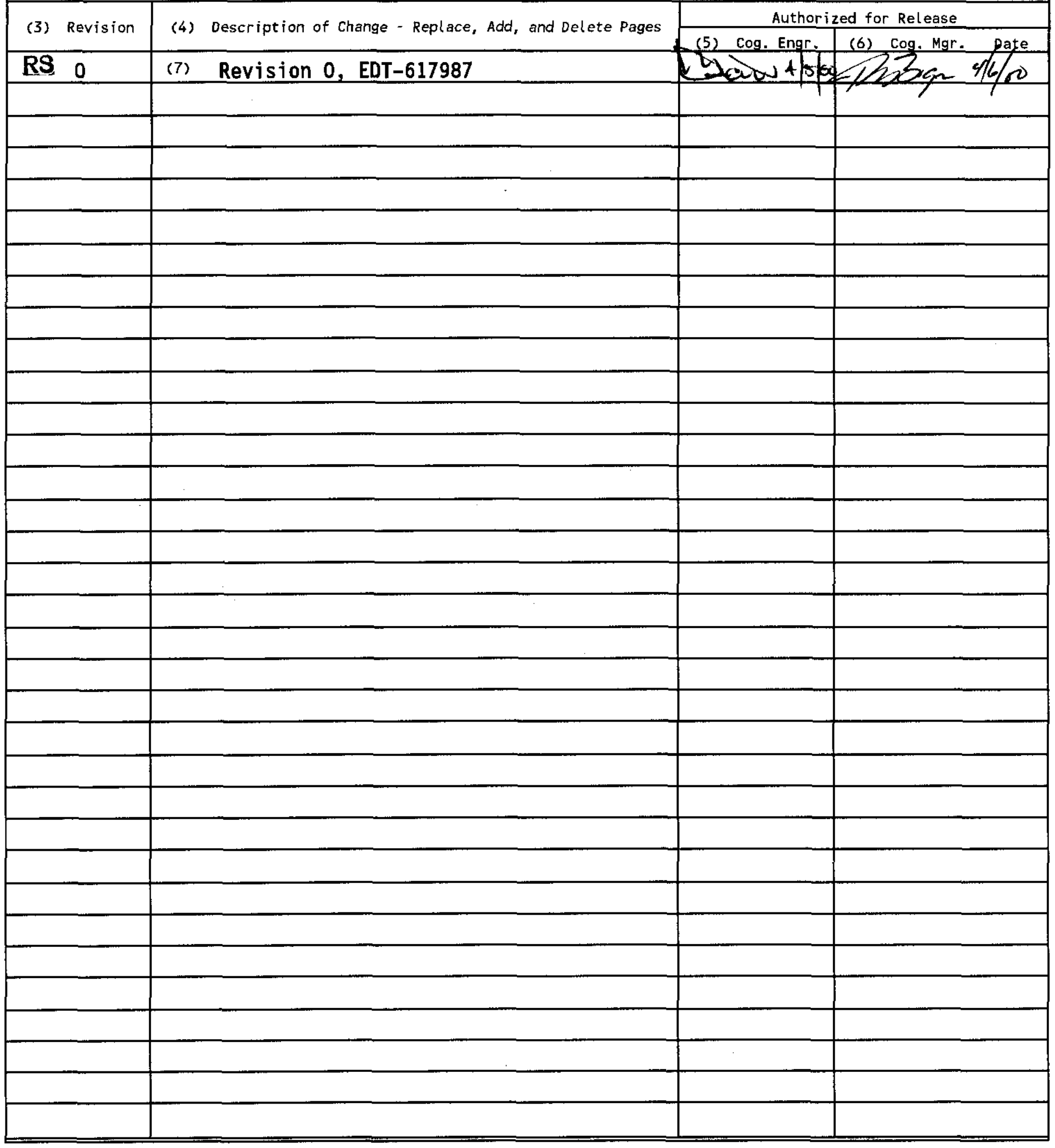




\title{
ENGINEERING TASK PLAN FOR PREPARATION OF THE LONG LENGTH CONTAMINATED EQUIPMENT TRANSPORT SYSTEM (LLCETS) FOR DEPLOYMENT (ETN-98-0007)
}

\author{
Prepared for \\ CH2M-HILL Hanford Group \\ Characterization Engineering Group \\ by \\ D. F. HICKS \\ NUMATEC HANFORD CORPORATION
}




\section{TABLE OF CONTENTS}

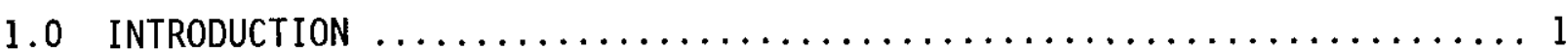

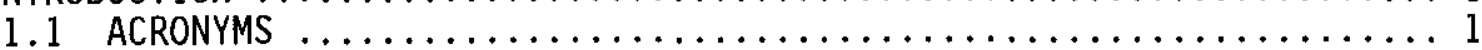

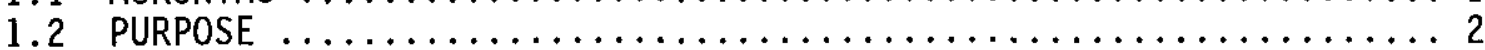

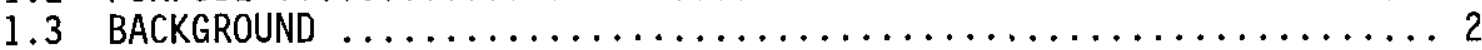

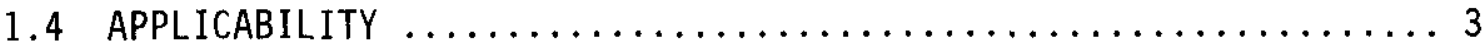

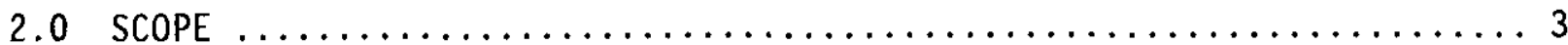

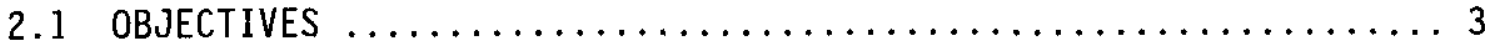

2.2 DELIVERABLES $\ldots \ldots \ldots \ldots \ldots \ldots \ldots \ldots \ldots \ldots \ldots \ldots \ldots \ldots, \ldots \ldots \ldots, \ldots \ldots \ldots$

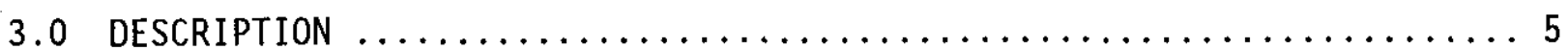

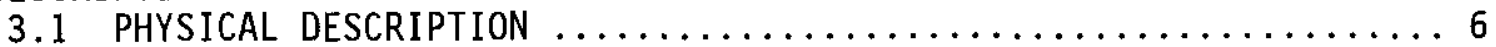

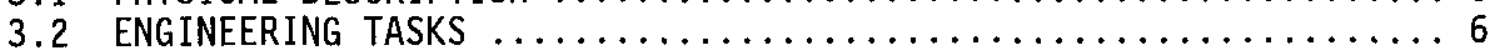

3.3 VERIFICATION AND TECHNICAL REVIEWS AND

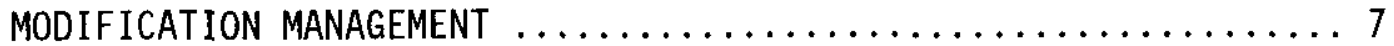

3.4 SOFTWARE DEVELOPMENT TASKS $\ldots \ldots \ldots \ldots \ldots \ldots \ldots \ldots \ldots \ldots \ldots \ldots$

3.5 PROCUREMENT/FABRICATION TASKS $\ldots \ldots \ldots \ldots \ldots \ldots \ldots \ldots \ldots \ldots$

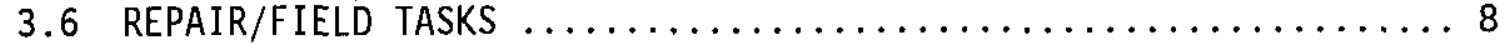

3.7 PRE-OPERATIONAL AND OPERATIONAL TESTS (TEST AND EVALUATION) $\ldots .8$

3.8 ACCEPTANCE FOR BENEF ICIAL USE (ABU) $\ldots \ldots \ldots \ldots \ldots \ldots \ldots \ldots$.

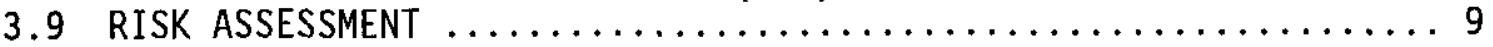

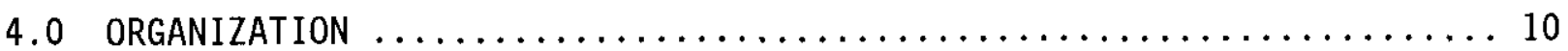

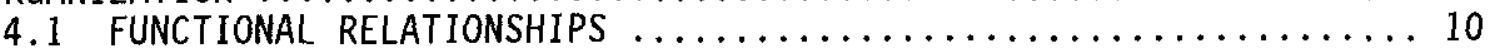

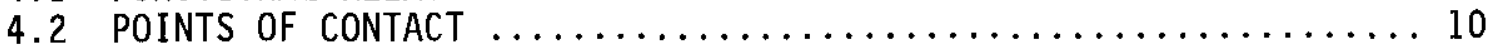

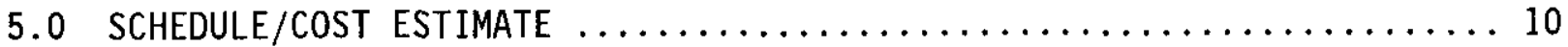

6.0 CONFIGURATION MANAGEMENT $\ldots \ldots \ldots \ldots \ldots \ldots \ldots \ldots \ldots \ldots \ldots \ldots \ldots \ldots \ldots \ldots$

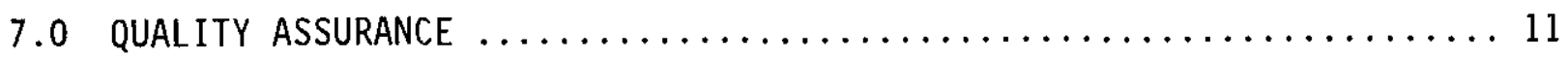

8.0 SAFETY AND AUTHORIZATION BASIS $\ldots \ldots \ldots \ldots \ldots \ldots \ldots \ldots \ldots \ldots \ldots \ldots \ldots \ldots \ldots$

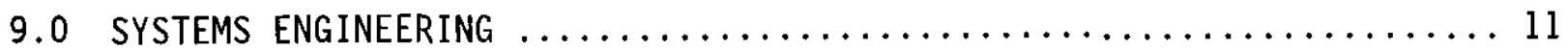

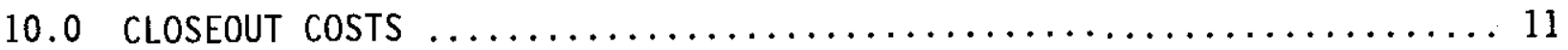

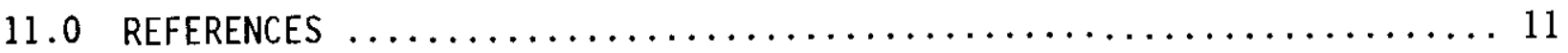

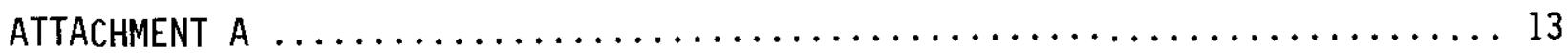

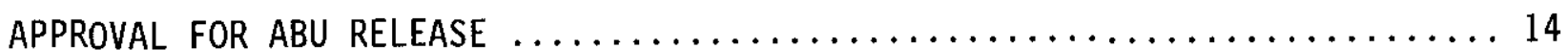

TABLES

1. Cost/Schedu1e/Resource Summary - LLCERS TRAILERS $\ldots \ldots \ldots \ldots \ldots \ldots . . \ldots 15-21$ 
RPP-5684, REV. 0

\title{
ENGINEERING TASK PLAN
}

\author{
(ETN-98-0007)
}

\section{PREPARATION OF THE LONG LENGTH CONTAMINATED EQUIPMENT TRANSPORT SYSTEM (LLCETS) FOR DEPLOYMENT}

\subsection{INTRODUCTION}

\subsection{ACRONYMS}

The meanings of acronyms used in this plan are provided below:

$\begin{array}{ll}\text { AB } & \text { Authorization Basis } \\ \text { ABU } & \text { Acceptance for Beneficial Use } \\ \text { CE } & \text { Characterization Engineering } \\ \text { CEIS } & \text { Cost Estimating Input Sheet } \\ \text { CHG } & \text { CH2MHILL Hanford Group, Inc. } \\ \text { CM } & \text { corrective maintenance } \\ \text { CP0 } & \text { Characterization Project Operations } \\ \text { DA } & \text { Design Authority } \\ \text { ECN } & \text { Engineering Change Notice } \\ \text { EDT } & \text { Engineering Data Transmittal } \\ \text { ETP } & \text { Engineering Task Plan } \\ \text { FGEAB } & \text { Flammable Gas Equipment Advisory Board } \\ \text { ESR } & \text { Engineering Service Request } \\ \text { FSAR } & \text { Final Safety Analysis Report } \\ \text { FY } & \text { fiscal year } \\ \text { JCS } & \text { Job Control System } \\ \text { NHC } & \text { Numatec Hanford Corporation } \\ \text { LLCE } & \text { long length contaminated equipment } \\ \text { LLCERS } & \text { long length contaminated equipment removal system } \\ \text { LLCETS } & \text { long length contaminated equipment transport system } \\ \text { PM } & \text { preventive maintenance } \\ \text { PMP } & \text { preventive maintenance procedure } \\ \text { QA } & \text { Quality Assurance } \\ \text { RCRA } & \text { Resource Conservation Recovery Act } \\ \text { RMW } & \text { radioactive mixed-waste } \\ \text { RPP } & \text { River Protection Project } \\ \text { RSO } & \text { Retrieval Support Operations } \\ \text { RT } & \text { receiver trailer }\end{array}$


RPP-5684, REV. 0

$\begin{array}{ll}\text { SARP } & \text { Safety Analysis Report for Packaging } \\ \text { SSC } & \text { system, structure, or component } \\ \text { TBR } & \text { Technical Basis Review } \\ \text { TRUM } & \text { transuranic mixed waste }(>100 \eta \mathrm{Ci} / \mathrm{g}) \\ \text { TT } & \text { transport trailer } \\ \text { USQ } & \text { unreviewed safety question } \\ \text { VI } & \text { vendor information } \\ \text { WMNW } & \text { Waste Management Federal Services Northwest }\end{array}$

\subsection{PURPOSE}

Within the constraints of FY-2000 funding, the purposes of this plan are to summarize interfaces between CE and other RPP organizations, and to define the scope of LLCETS preparations for mobilization by CPO.

Because the LLCETS may be deployed by any RPP organization or by any of the several different 1 ine item projects, e.g., W-211, Initial Tank Retrieval System, W-519, Privatization Phase I Infrastructure, an important responsibility of CE is maintaining a viable DA presence.

\subsection{BACKGROUND}

The process path for removal of LLCE from RPP waste tanks is presented in HNF-1998. The LLCETS trailers have never been deployed in RPP, but they are required for the disposal process described in HNF-1998.

CE is the currently designated owner, custodian, and steward of the LLCETS trailers, and will provide configuration management with preventive and corrective maintenance. CE will turn over the LLCETS to CPO per the ABU process, and will continue to provide needed LLCETS support to CPO after turnover. The HNF-1998 process path document describes deployment of the LLCETS in more detail.

The concepts of LLCETS "system design" and "Design Authority" are separate and distinct from the concept of "ownership". DA is retained within the CE organization for all issues affecting the LLCETS design baseline, and RPP user organizations shall accept CE as the LLCETS DA. Any LLCETS design issues which interface directly with tank farm SSCS may also require approval of the affected tank farm DA.

CPO plans to share LLCETS items with both plant forces and construction forces to complete RPP programmatic objectives. Other hardware owner organizations will make separate decisions on sharing of equipment under their direct control.

LLCE items destined for eventual removal from Hanford waste tanks can be from 12 to 55 feet long. Approximately 1,300 LLCE items are currently installed in waste tank risers. If these LLCE do not interfere with 
RPP-5684, REV. 0

retrieval activities or restrict normal tank operations, there are no current plans to remove them, however, as many as 100 LLCE items may have to be removed in the future to support tank waste retrieval activities and tank waste inventory management schedules. As discussed in HNF-1998, the LLCE disposal plan includes using the LLCETS to transport qualifying LLCE items to the RCRA compliant RMW landfill (trenches No. 31 and 34 ) for disposal.

For planning purposes, five percent of removed LLCE items will be assumed to either be suspect TRUM or to have calculated hydrogen generation rates that do not meet the criteria for RMW disposal. Using current guidance, these LLCE items will be diverted to T-Plant and stored until a final method of disposal can be determined.

When an LLCE item is removed for maintenance replacement reasons, e.g., the failed 104-AW transfer pump, plant forces will perform the removal as noncovered work per the Davis-Bacon Act.

\subsection{APPLICABILITY}

This plan applies to all RPP facilities for which operations are now authorized by the $A B$. The provisions of this plan extend to all approved LLCETS activities.

\subsection{SCOPE}

\subsection{OBJECTIVES}

The scope of the task presented in the introduction is to achieve full operational readiness of a physically complete, accurately documented, and fully accepted LLCETS (the RT and the TT) by the end of FY-2000.

Engineering Service Request 99-028 has been prepared for this task.

\subsection{DEL.IVERABLES}

- Provide detailed reports on what parts need to be replaced or upgraded.

Deliverable: A detailed report on the RT and the TT describing which parts need replacement or upgrade is prepared and approved.

- Prepare/update PM work packages, as required, to cover replacement and/or repair of LLCETS equipment and systems. 
RPP-5684, REV. 0

Deliverable: As needed, PM work packages are prepared and approved for general maintenance replacement and/or repair of the RT and TT equipment and systems.

- As required, overhaul and/or repair the LLCETS trailers to working order.

Deliverable: RWR work activities for the RT and the TT are complete.

- Prepare draft PM requirements for the RT and the TT.

Deliverable: Draft PM procedures for the RT and TT equipment and systems are prepared. Vendor maintenance requirements are incorporated into applicable work documents.

- Prepare PM work packages for LLCETS equipment.

Deliverable: All PM work packages are identified, prepared, and approved.

- Perform all recommended PM on LLCETS equipment.

Deliverable: All PM work packages are completed, and LLCETS equipment is current on all recommended PMs and calibrations.

- Prepare LLCETS draft operating instructions for the RT and the TT.

Deliverable: Draft operating and prerequisite instructions for the RT and TT equipment and systems are prepared.

- Perform a functional test of the RT and TT equipment and systems.

Deliverable: Functional testing of the RT and TT is complete, and a test report has been written and released.

- Prepare a maintenance program plan for approval in FY-2000 for the LLCETS (RT and TT).

Deliverable: A LLCETS maintenance program $\mathrm{plan}$ is prepared and approved.

- Implement a PM program for the LLCETS. 
RPP-5684, REV. 0

Deliverable: Implementation of a LLCETS PM program is complete, including establishing the spare parts inventory.

- Provide configuration control (cognizant engineer and DA) for all LLCETS vendor information, engineering drawings, software, and specifications.

Deliverable: A LLCETS Cognizant Engineer and DA are selected and formally designated.

- Maintain the SARP and the LLCETS vendor files.

Deliverable: The SARP upgrade is approved and released for use. Vendor information, including the LLCETS vendor drawings, is in a VI file.

- Prepare Hanford site drawings for the LLCETS as necessary.

Deliverable: Using vendor drawings and other acceptable design inputs, $\mathrm{H}-14$ and/or other Hanford site drawings are prepared, issued, and released as necessary to document the LLCETS basel ine design. Outstanding ECNs meeting the HNF-IP0842 criteria for incorporation provided in Vol. IV, Section 4.25, "Engineering Drawings", Part 5.5.1, are incorporated into the affected design baseline documents.

- Upgrade/validate VAXGAP, LLCEDATA and LLCECALC software to current RPP requirements and establish software configuration control.

Deliverable: The LLCEDATA and LLCECALC computer software is upgraded to the applicable RPP criterion and is validated. The VAXGAP computer software is validated. Configuration control of software is established.

- Complete a partial ABU with turnover of the LLCETS equipment to CPO. Turnover includes the RT and TT with sufficient operating instructions to enable support of $\mathrm{p} 7$ anned maintenance activities.

Deliverable: A partial $A B U$ is completed and approved. Turnover of the LLCETS equipment to CPO is complete.

\subsection{DESCRIPTION}

\subsection{PHYSICAL DESCRIPTION}


RPP-5684, REV. 0

There are several hundred underground tanks in use in the 200 Area tank farms for the storage of high-level and low-level RMW. The most significant of these tanks range in capacity from 2,003,000 to 4,385,000 liters $(530,000$ to $1,160,000$ gallons). The oldest tanks are 149 singlewalled tanks, called SSTs, which are no longer used actively. Most of these SSTs have been interim stabilized by removing their inventory of free liquids and by isolating them from other liquid waste stream additions. Twenty-eight newer double-walled tanks, called DSTs, contain liquid and sludge wastes and provide most of the current active storage capacity.

The current RPP mission is to maintain safe, retrievable storage of tank waste. Tank waste retrieval, treatment, and final disposal will be performed by others at a later time.

The dedicated set of equipment items needed to implement the process path agreements summarized in HNF-1998 is collectively referred to as the LLCERS, with the LLCETS being a subset of the LLCERS. The two major components of the LLCETS are the RT and the TT. An earlier trailer design was used in 1995 to transport seven thermocouple trees that were removed from $A Z-101$, as the current RT and TT were not yet available for use. The RT is used to receive the bagged LLCE from the crane, lower it from a vertical to a horizontal position, and package the bagged LLCE by pushing it horizontally into a disposal container on the TT. Packages qual ified for disposal are sealed and grout filled, and the TT is used to transport the packaged LLCE to its disposal location. Packages to be stored at T-Plant are not grouted.

\subsection{ENGINEERING TASKS}

The tasks below are required for completion of the scope:

- Generate a complete inventory of all existing spare parts for the LLCETS. Create a listing of recommended spare parts, and begin the procurement process to obtain those spare parts which are not already in inventory.

- Identify the LLCETS DESIGN BASELINE documentation, e.g., essential, support and general drawings, ECNs, VI files, FGEAB evaluations, equipment specifications. Fill in the gaps where information is missing.

- Identify, 1ist, assess adequacy, and fill in TECHNICAL BASELINE gaps, as necessary, for the remainder of the LLCETS.

- Complete a stewardship plan for the LLCETS items controlled by CE.

- Provide a listing of all LLCETS design verification documentation. 
RPP-5684, REV. 0

- Develop typical plans/processes/strategies for tank farm deployment of LLCETS items:

- Create a pre-deployment equipment checklist for review.

- Provide an interface point for SARP requirements.

- Compile a list of maintenance and operating instructions needed by the LLCETS for an LLCE maintenance replacement activity. Prepare a plan for their preparation and validation.

- Prepare draft LLCETS maintenance procedures.

- Prepare and issue an LLCETS operating instructions manual.

- Complete partial turnover of the LLCETS trailers to CPO in a manner compliant with the ABU process.

- Update applicable TBR and CEIS documents.

\subsection{VERIFICATION AND TECHNICAL REVIEWS AND MODIFICATION MANAGEMENT}

Design verification is performed to ensure that a design is technically adequate; that design inputs are evaluated and verified for their impact on the design; and that the design meets the applicable requirements for environmental qualification, quality, safety, and performance at a reasonable cost. The extent of design verification required for any individual item will be appropriate for its complexity and importance to the LLCETS. To provide evidence that design verification has occurred, verification documentation of the design is referenced, as appropriate, in design basis documents, in EDTs for released documents, or in Field 14b of released ECNs, "Justification Details".

The design of the LLCETS is understood to have been verified per CHG2000c, and one of the tasks of this ETP is to document and provide a listing of all design verification documentation as a part of the configuration control deliverable. Section 3.2 ENGINEERING TASKS will examine the available documentation on design verification. Depending on the results, additional design verification activities may be required.

If design of a new safety-class SSC were to be required for future LLCETS operation, appropriate design verification activities will be performed, including affected functional organization reviews and approvals. As documented in Chapter 3.0 of the FSAR and as defined in DOE-1994, however, safety-class SSCs are those whose preventive or mitigative function is necessary to keep hazardous material exposure to the public below the offsite evaluation guidelines. The SSCs that 
RPP-5684, REV. 0

comprise the LLCETS are grouped with other RPP tools such as cranes and trucks. In general, RPP tools do not perform safety functions, and none are identified in Chapter 3.0 of the current revision of the FSAR as either safety SSCs or defense-in-depth SSCs. LLCETS equipment items, however, may be required to incorporate specific design attributes and/or conform to specific procedural constraints to qualify for deployment in RPP facilities, and validation of the necessary controls will be accomplished by the design verification and USQ processes.

\subsection{SOFTWARE DEVELOPMENT TASKS}

Two software applications, LLCEDATA and LLCECALC, are already developed, verified, and validated for real time gamma assay of an LLCE item during its removal from a waste tank, and are described in HNF-1995. The VAXGAP software translates gamma spectra into activity data, and provides input to the LLCEDATA software. These software applications are not vulnerable to $C Y-2000$ problems. Two FY-2000 upgrade tasks for the LLCECALC software are planned, the addition of an algorithm for hydrogen generation rates, and the removal of excessive conservatism from the calculation of TRUM.

\subsection{PROCUREMENT/FABRICATION TASKS}

Procurement of some materials, e.g., spare parts and consumables, will likely be required to complete the scope of this task.

\subsection{REPAIR/FIELD TASKS}

The LLCETS items are portable, and each individual item has been designed so that it can be transported to the point of application for use. No permanent installation of an LLCETS item is identified or required.

The full participation of Maintenance, CPO, and Engineering will be required to gain operability of the LLCETS. Maintenance will provide skilled resources; $C P O$ will provide activity and priority integration; and Engineering will provide configuration management, program coordination, and project control.

\subsection{PRE-OPERATIONAL AND OPERATIONAL TESTS (TEST AND EVALUATION)}

Extensive qualification testing of the LLCETS components, e.g., RT and TT, has already been performed, and a listing of the applicable documentation will be compiled as a deliverable of this task. In addition, a complete functional test of the TT and the RT will be performed prior to a declaration of readiness, and will be documented in a test report.

\subsection{ACCEPTANCE FOR BENEFICIAL USE (ABU)}


RPP-5684, REV. 0

The ABU process is defined in CHG-1999, and supplemental implementing instructions are provided in CE-1999. The guidance in these two documents will be used to ensure that the necessary activities, documentation, and associated implementing actions are completed for the LLCETS before turnover to CPO in FY-2000. The documentation required prior to partial Acceptance for Beneficial Use is listed on the attached Form A-6002-445.

The $A B U$ process also identifies the responsibilities and requirements needed to verify that CPO has received all documentation needed for proper operation and maintenance of the LLCETS.

CE, CPO, and other independent reviewers will approve the 1 isting of applicable ABU requirements for the LLCETS. At turnover, CPO accepts the LLCETS based on satisfactory completion of the listed partial ABU requirements. The assay system software will remain under the control of either CE or a designated software accountability person.

\subsection{RISK ASSESSMENT}

Fiscal year 2000 funding authorization (130.B16) for the LLCETS (the RT and the TT) is established for the following tasks:

- Inspect/troubleshoot the LLCETS.

- Prepare maintenance procedures and operating instructions for the LLCETS.

- Overhaul/repair the LLCETS components as required.

- Implement configuration control for the LLCETS.

Higher priority RPP work in FY-2000 may create equipment and resource conflicts which could stop or delay any or all of the tasks 1isted above.

In addition, WMNW may be funded in FY-2000 to validate the LLCEDATA and LLCECALC characterization software. Configuration control of the software will be confirmed. The WMNW work scope may also include upgrading the $\angle L C E C A L C$ transuranic characterization algorithm to remove excessive conservatism, as the impact of an LLCE item not meeting RCRA requirements for disposal in the 200 west Area mixed waste 1 andfill trenches is a major constraint. If the best resources to optimize the LLCECALC software are not available when needed, large economic penalties could be levied on RPP for future LLCE disposal activities.

Unexpected delays or requests for extensive changes to any of these activities may require additional FY-2000 funding to complete anticipated preparation activities. If supplemental funds were not immediately available, the assumed availability of the LLCETS to support 
RPP-5684, REV. 0

construction projects in FY-2001 (e.g., Project W-211) and plant forces in FY-2002 (e.g., maintenance replacement of the failed 104-AW transfer pump) could be impacted.

\subsection{ORGANIZATION}

\subsection{FUNCTIONAL RELATIONSHIPS}

$\begin{aligned} \text { CPO } & \text { Physical equipment custodian/user/operator } \\ \text { RSO } & \text { Client } \\ \text { W-211 } & \text { Alternate user/operator (as borrower) } \\ \text { CE } & \begin{array}{l}\text { Design and project activity coordinator/Technical } \\ \text { Baseline owner/ETP activity coordinator }\end{array}\end{aligned}$

\subsection{POINTS OF CONTACT}

$\begin{array}{llll}\text { JE Al1 ison (CHG) } & 373-3037 & \text { R3-72 } & \text { RSO } \\ \text { ML McElroy (CHG) } & 373-5588 & \text { S7-07 } & \text { QA } \\ \text { RM Boger (NHC) } & 376-3355 & \text { S7-12 } & \text { Responsible Engrg Manager } \\ \text { RG Brown (CHG) } & 373-5694 & 57-12 & \text { Cognizant Engineer } \\ \text { CA Esvelt (CHG) } & 373-3577 & 57-12 & \text { Cognizant Engineer } \\ \text { DF Hicks (NHC) } & 376-0196 & 57-12 & \text { Project Lead } \\ \text { CD Jackson (CHG) } & 376-0531 & 57-34 & \text { Safety } \\ \text { GP Janicek (CHG) } & 376-2225 & 57-12 & \text { Design Authority } \\ \text { WS Josephson (WMNW) } & 372-8597 & \text { H1-11 } & \text { Transportation Services } \\ \text { DE Legare (NHC) } & 376-3489 & \text { R3-47 } & \text { Consultant } \\ \text { JF Sickels (CHG) } & 373-0259 & \text { S7-03 } & \text { CP0 } \\ \text { JS Schofield (CHG) } & 373-2245 & \text { S7-12 } & \text { Cognizant Engrg Manager } \\ \text { JE Van Beek (CHG) } & 372-2813 & \text { S2-48 } & \text { W-21l Project Manager }\end{array}$

\subsection{SCHEDULE/COST ESTIMATE}

The estimated cost to prepare the LLCETS for deployment is $\$ 804,000.00$, with an estimated completion date of September 20, 2000 as shown on the attached schedule.

\begin{tabular}{lr} 
FY-2000 Activity & \multicolumn{1}{c}{ Cost (\$) } \\
\cline { 2 - 2 } Inspect/Troubleshoot & $\$ 15,000.00$ \\
Prepare/Update RCRS & $15,000.00$ \\
Overhaul/Repair LLCETS & $375,000.00$ \\
Prepare Review/Issue PM Procedures & $126,000.00$
\end{tabular}


RPP-5684, REV. 0

\author{
Implement Configuration Control Engineering 273,000.00
}

Total $\ldots \ldots \ldots \ldots . \quad \$ 804,000.00$

\title{
6.0 CONFIGURATION MANAGEMENT
}

A11 LLCETS items were fabricated to approved engineering design media. The LLCETS equipment design will be under configuration management following completion of this task.

\subsection{QUALITY ASSURANCE}

A1 though most components of the LLCETS are classified as General Service, some items may be classified as General Service/Enhanced Quality (GS/EQ) per RPPMD-026, Rev. 0, for procurement purposes. The GS/EQ components have specific attributes and/or were engineered for specific performance criteria requiring documentation during the procurement process. Components and replacement parts for these GS/EQ LLCETS items will require QA receipt inspection to ensure compliance with purchase order requirements.

\subsection{SAFETY AND AUTHORIZATION BASIS}

The RPP AB for this project is provided in CHG-2000d, Attachment A. Design, staging, mobilization, operation, and demobilization activities affecting LLCETS items will comply with al1 RPP AB requirements. A11 LLCETS equipment modifications and approved operating instructions/maintenance procedures will be evaluated through the USQ process if required by Section 5.4 of CHG-2000d.

\subsection{SYSTEMS ENGINEERING}

There is an operational need for mobile platforms that can receive, package, and transport an LLCE item for disposal. Work Breakdown Structure 1.1.4.1.1.10.9.1 has been established to ensure compatibility of all physical, functional, and technical program interfaces in a manner which optimizes the total system definition and design.

\subsection{CLOSEOUT COSTS}

An estimated $\$ 9,750.00$ would be required to closeout this task should it be terminated prior to completion.

\subsection{REFERENCES}


RPP-5684, REV. 0

CE, 1999, Desk Instruction: Acceptance For Beneficial Use (ABU), DI-CE004-02, Rev. 2, Characterization Engineering, Lockheed Martin Hanford Corp., Richland, Washington.

CHG, 1999, HNF-IP-0842, RPP Administration, Volume IV, Section 3.12, Acceptance of Structures, Systems, and Components for Beneficial Use, Rev. 1d, CH2MHILL Hanford Group, Inc., Richland, Washington.

CHG, 2000a, Tank Waste Remediation System (TWRS) Final Safety Analysis Report (FSAR), HNF-SD-WM-SAR-067, Rev. 1-F, CH2MHILL Hanford Group, Inc., Richland, Washington.

CHG, 2000b, Tank Waste Remediation System Technical Safety Requirements (TSR), HNF-SD-WM-TSR-006, Rev. 1-F, CH2MHILL Hanford Group, Inc., Richland, Washington.

CHG, 2000c, HNF-IP-0842, RPP Administration, Volume IV, Section 4.24, Design Verification, Rev. Od, CH2MHILL Hanford Group, Inc., Rich1and, Washington.

CHG, 2000d, HNF-IP-0842, RPP Administration, Volume IV, Section 5.4, Unreviewed Safety Questions, Rev. 12, Attachment A, CH2MHILL Hanford Group, Inc., Richland, Washington.

DOE, 1994, Preparation Guide for U.S. Department of Energy Nonreactor Nuclear Facility Safety Analysis Reports, D0E-STD-3009-94, U.S. Department of Energy, Washington, D.C.

HNF, 1995, LLCEDATA and LLCECALC for Windows ${ }^{\circ}$ Version 1.0, Volume $I$, User's Manual; Volume II, Technical Manual; and Volume III, Sof tware Verification \& Validation, HNF-3169, Rev. 0, Fluor Daniel Hanford Inc., Richland, Washington.

HNF, 1998, Long-Length Contaminated Equipment Disposal Process Path Document/ETN-94-0054A, HNF-SD-WM-ER-730, Rev. 1 (prepared by ARES Corporation under Agreement No. A52770, Task Order 001 as Report No. 987201-001, Rev. 1), Waste Management Federal Services Inc., Richland, Washington.

WHC, 1995, 42" Flexible Receiver Development Test Report, WHC-SD-W151TRP-002, Rev. 0, Westinghouse Hanford Company, Richland, Washington. 


\section{DOCUMENTATION REQUIRED from}

\section{Project}

PREPARATION OF THE LONG LENGTH CONTAMINATED EQUIPMENT TRANSPORT SYSTEM (LLCETS) FOR DEPLOYMENT

Prior to ACCEPTANCE FOR BENEFICIAL USE

\begin{tabular}{|c|c|c|c|}
\hline DESCRIPTION & RESPONSIBILITY & DESCR IPTION & RESPONSIBILITY \\
\hline 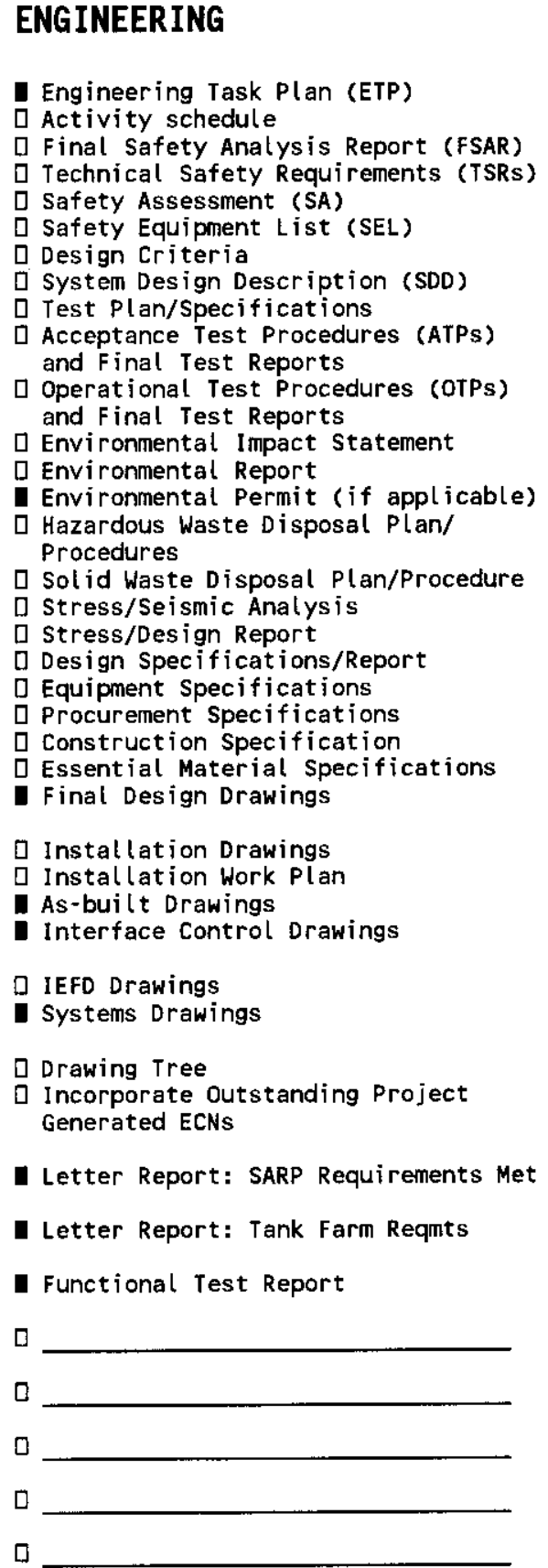 & $\begin{array}{l}\text { CA Esvelt/ } \\
\text { RG Brown } \\
\text { GW Wilson } \\
\text { CA Esvelt/ } \\
\text { RG Brown } \\
\text { CA Esvelt/ } \\
\text { RG Brown } \\
\text { DF Hicks } \\
\text { RG Brown } \\
\text { CA Esvelt/ } \\
\text { RG Brown }\end{array}$ & 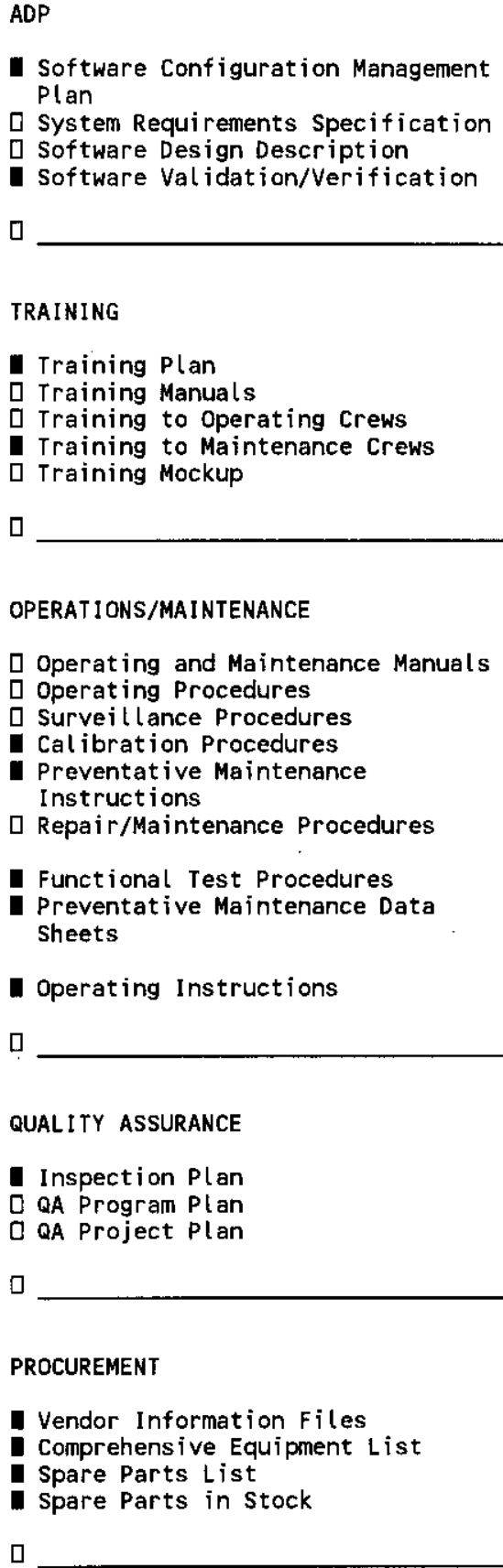 & $\begin{array}{l}\text { JC Akers } \\
\text { CA Esvelt } \\
\text { MN Hall } \\
\text { JC Akers } \\
\text { RG Brown }\end{array}$ \\
\hline
\end{tabular}


RPP-5684, REV. 0

\section{APPROVAL FOR ABU ISSUE/RELEASE}

\begin{tabular}{|c|c|c|c|}
\hline Name & & Signature & Date \\
\hline Cog Engineer & CA Esvelt & & \\
\hline Cog Engineer & RG Brown & & \\
\hline Cog Manager & JS Schofield & & \\
\hline Project Lead & DF Hicks & & \\
\hline Design Authority & GP Janicek & & \\
\hline Characterization Engrg & RM Boger & & \\
\hline Characterization Ops & JF Sickels & & \\
\hline QA & ML McElroy & & \\
\hline Safety & CA Jackson & & \\
\hline Environmental & LL Penn & & \\
\hline
\end{tabular}


RPP-5684, REV. 0
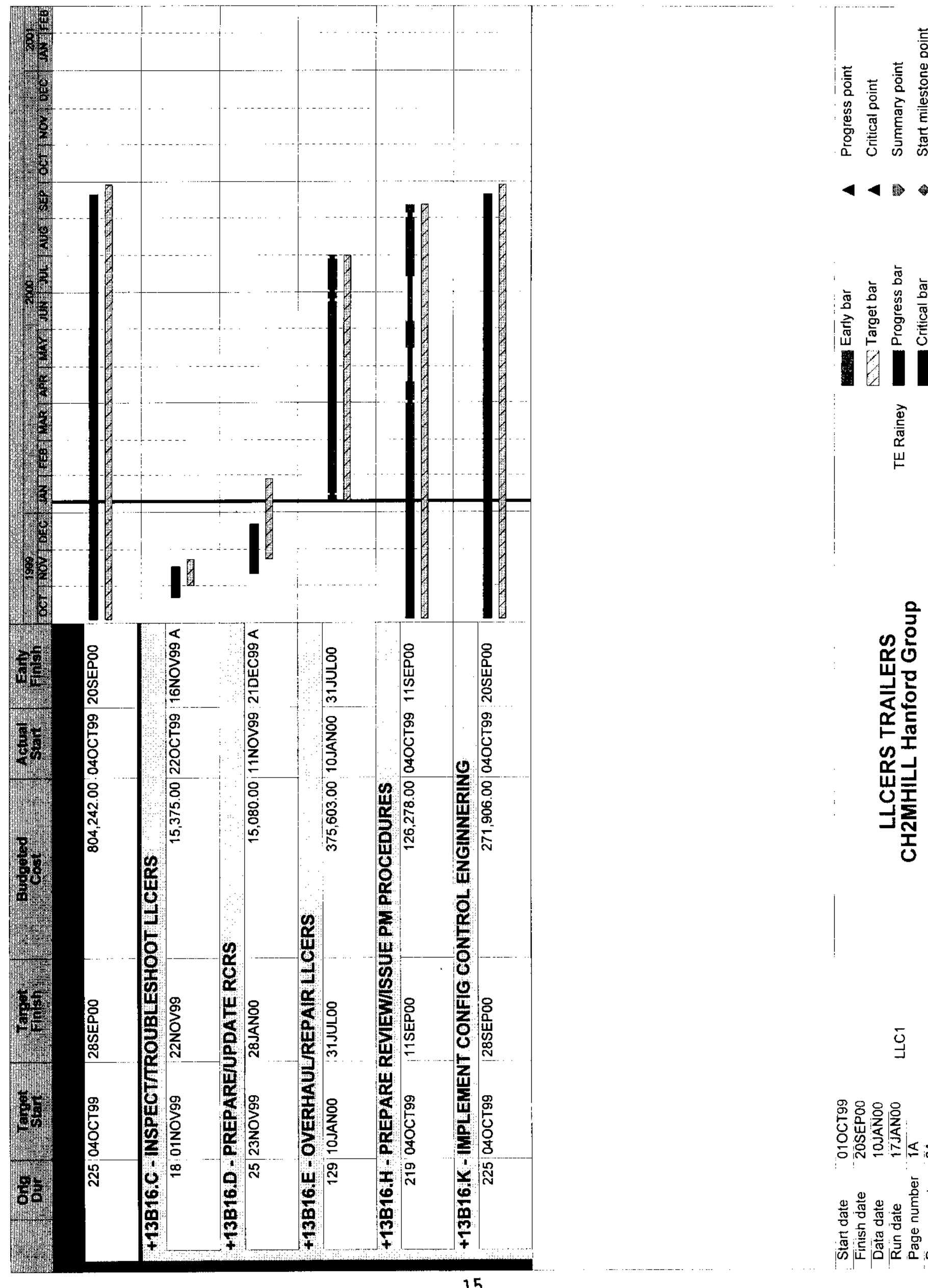

$\bar{g}$

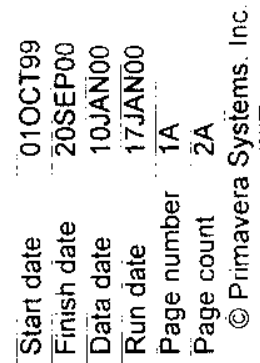


RPP-5684, REV. 0

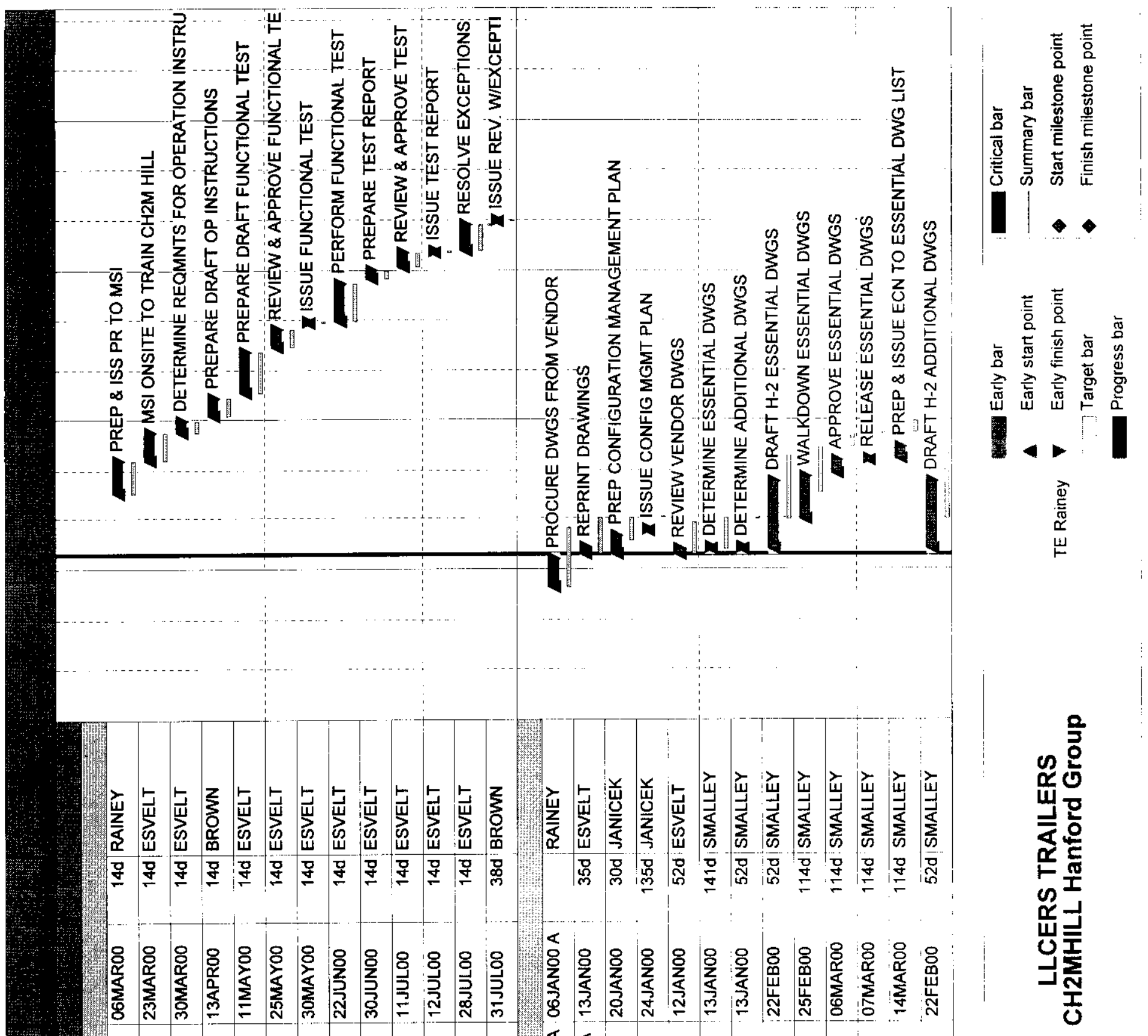

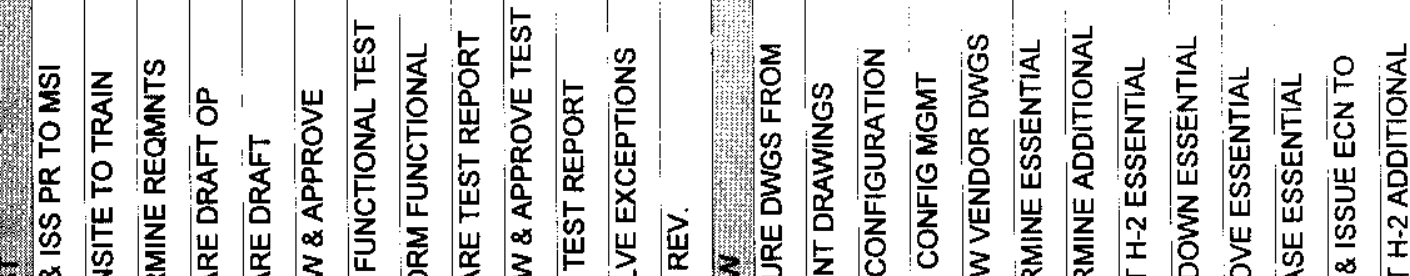

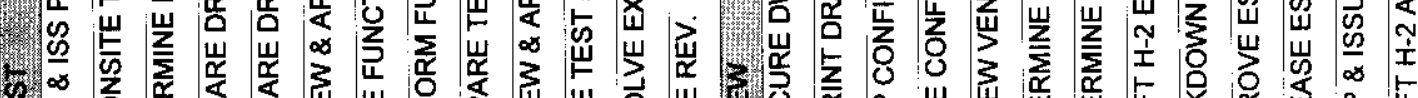

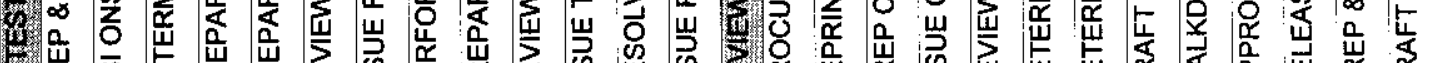

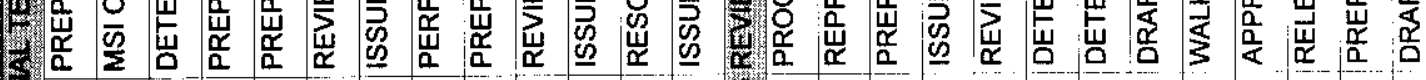

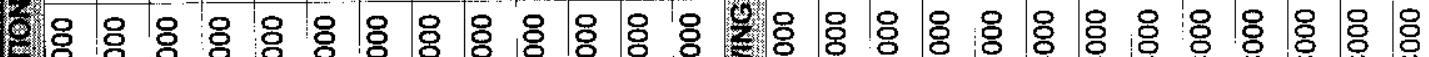
教曹

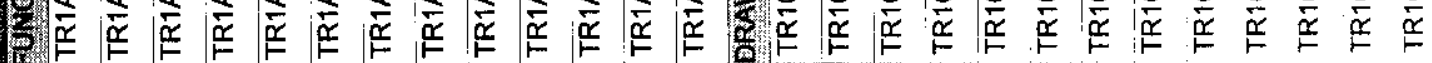


RPP-5684, REV. 0

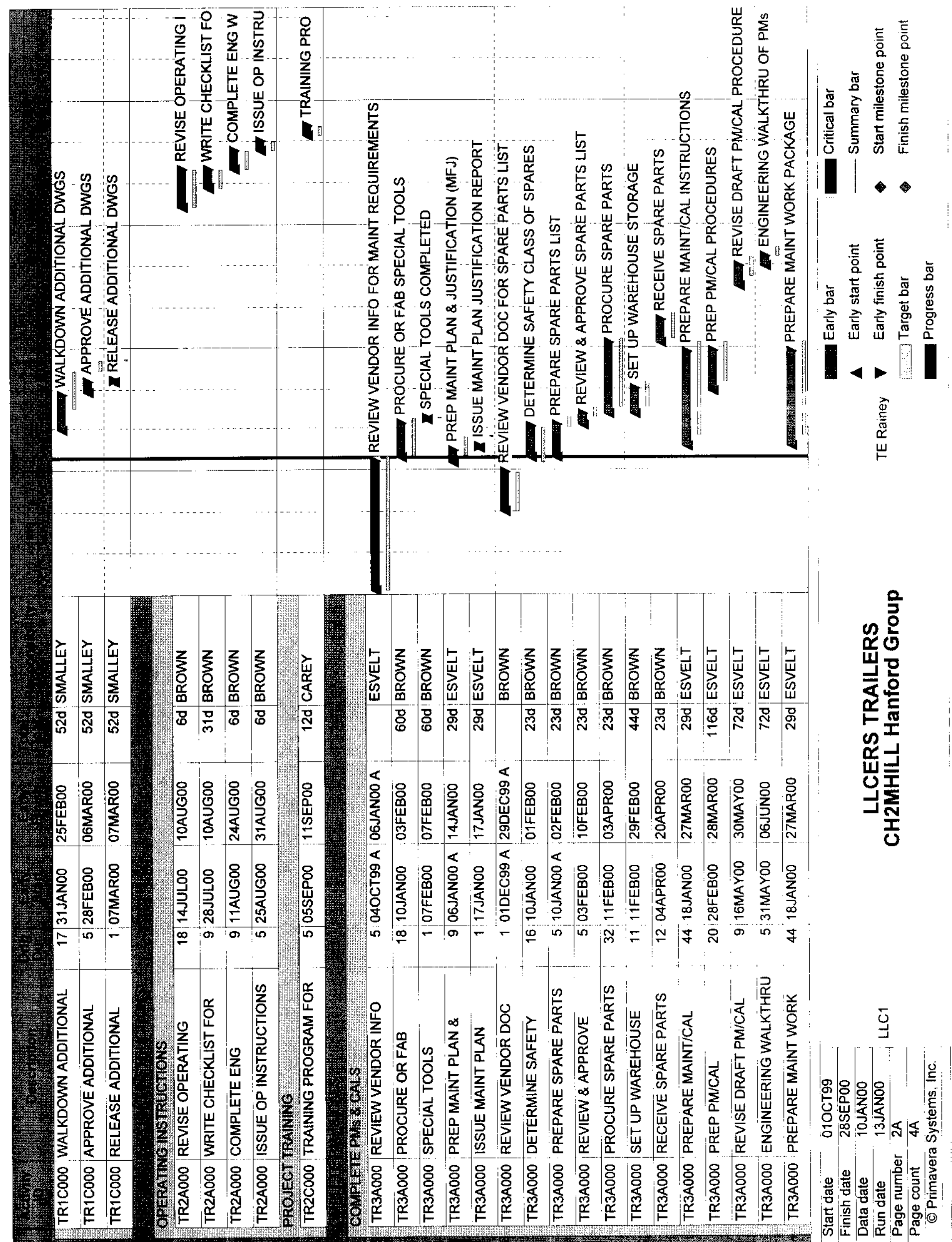


RPP-5684, REV. 0

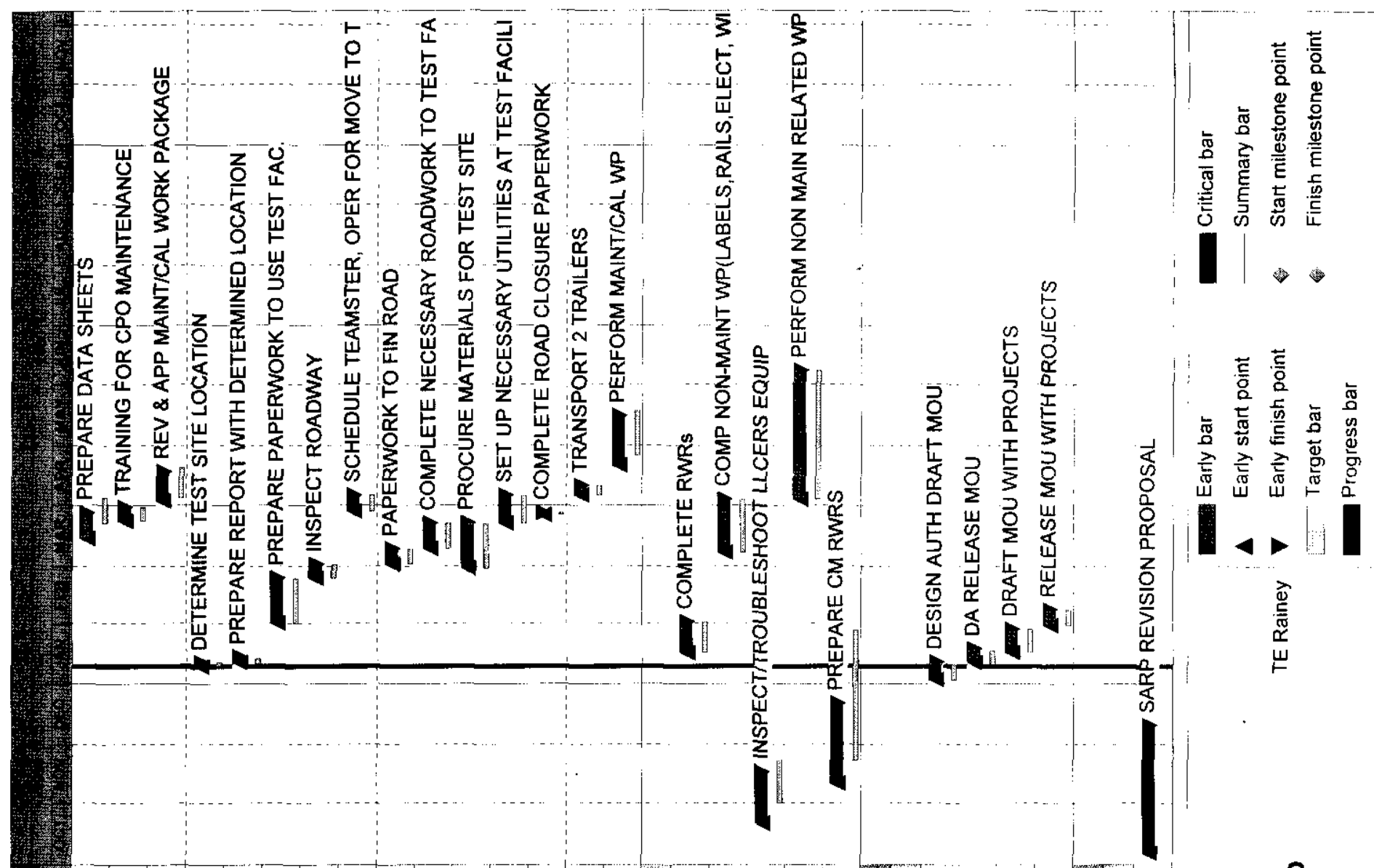

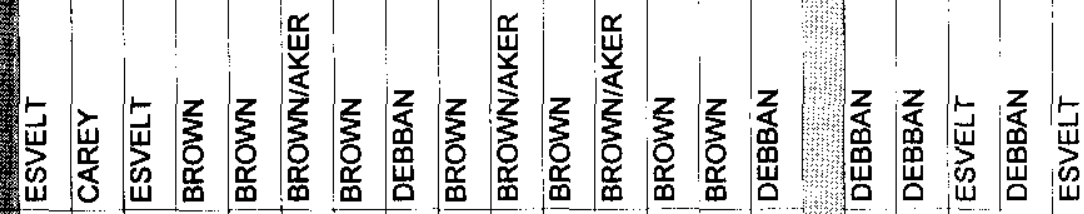

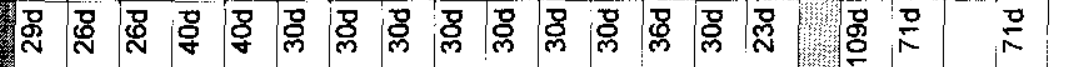

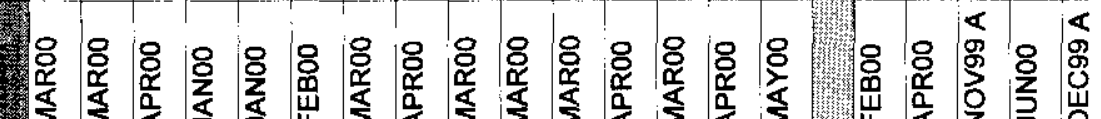

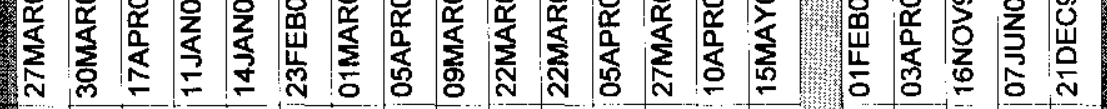
8 8 8 i

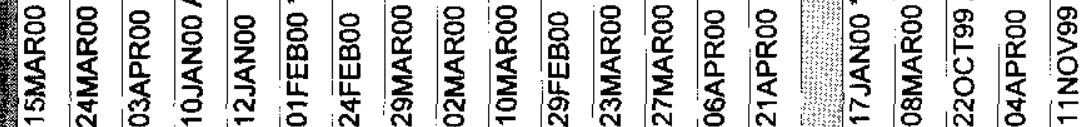
管

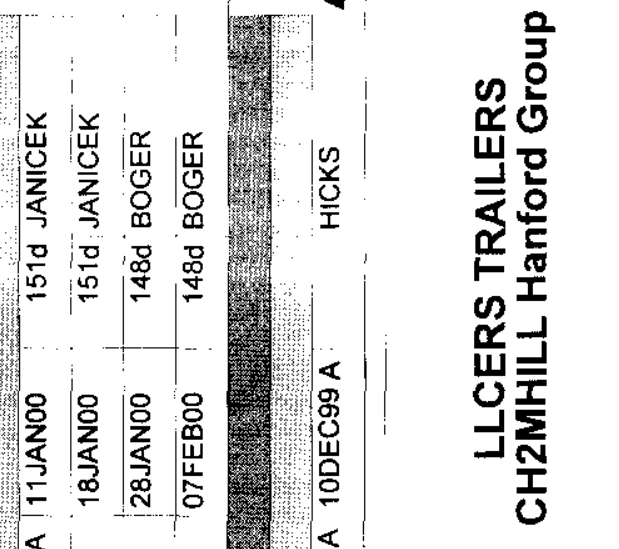

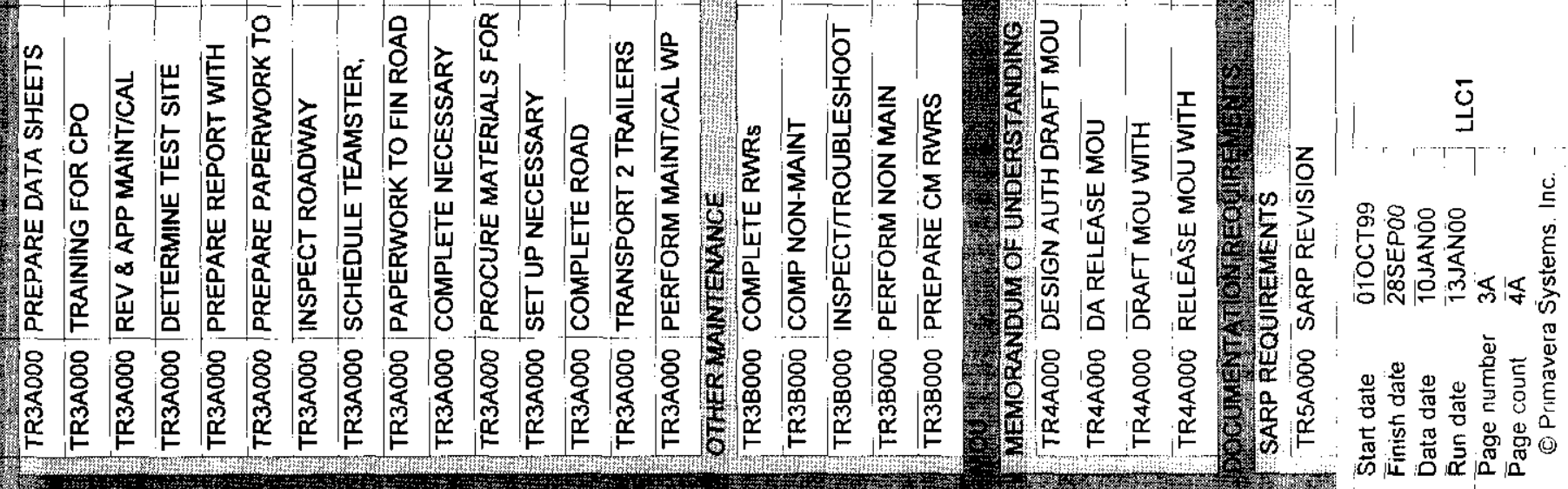


RPP-5684, REV. 0
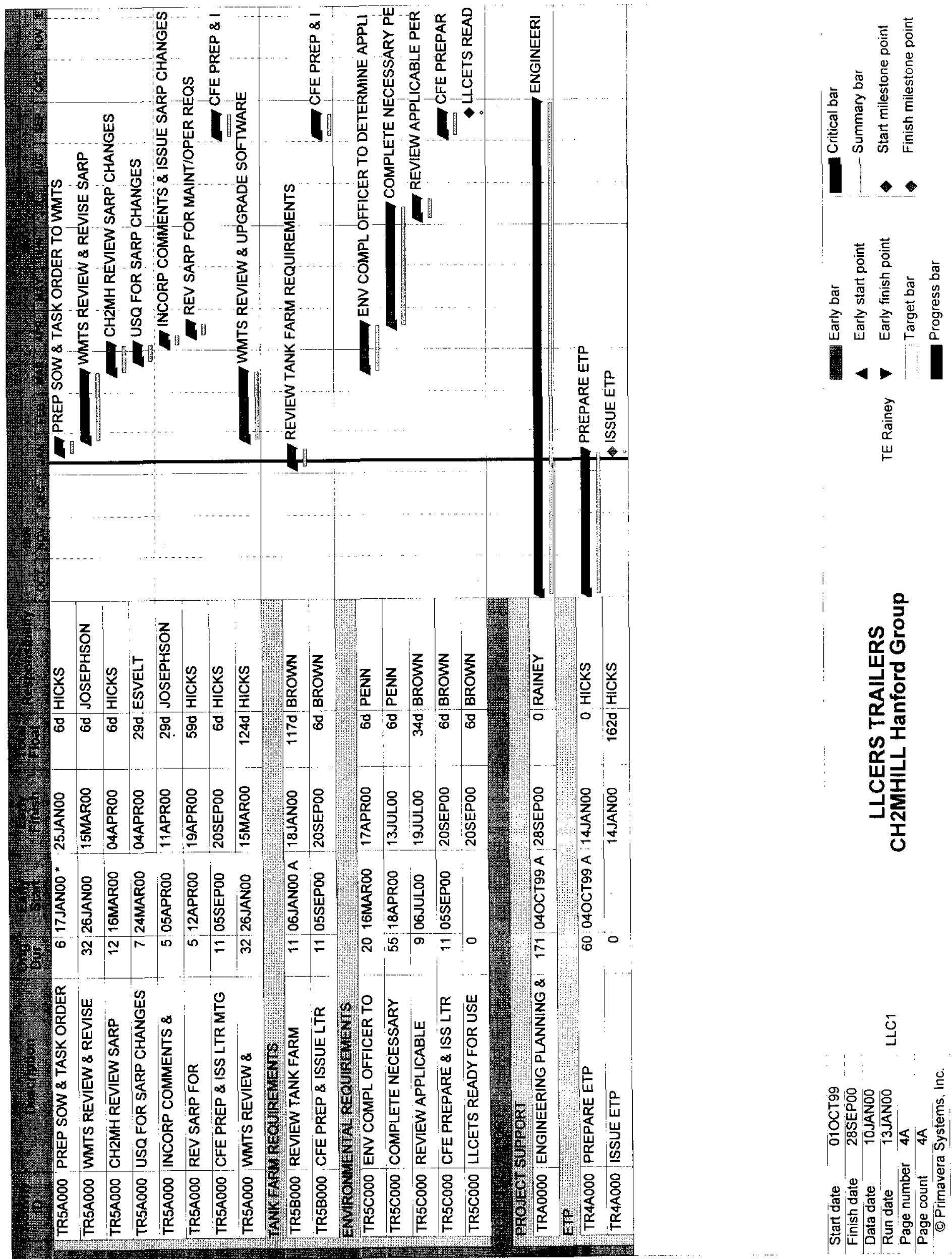

ভِ

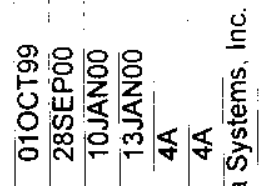

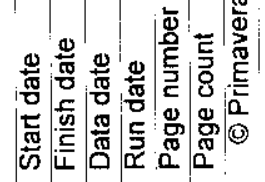


RPP-5684, REV. 0

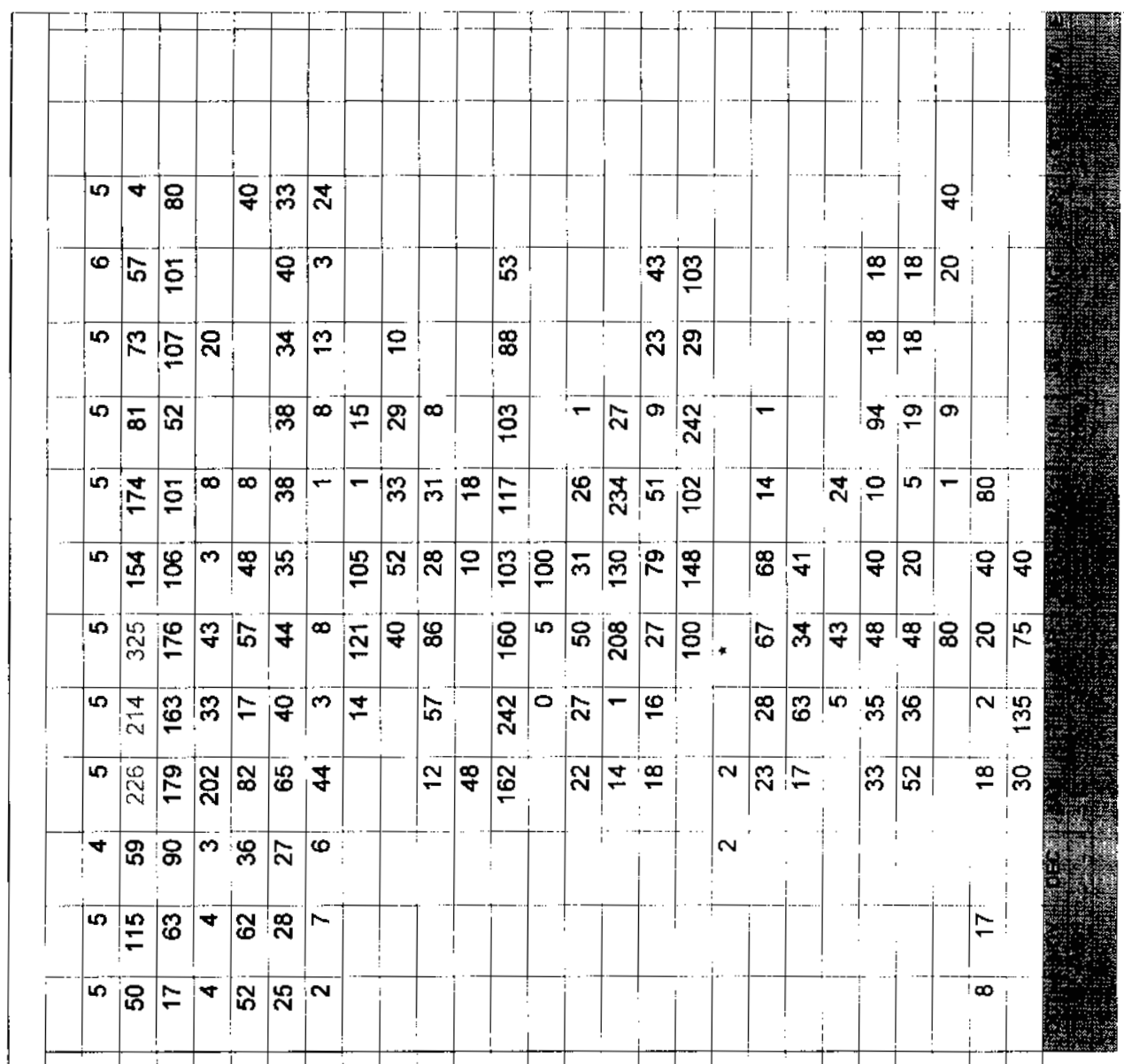

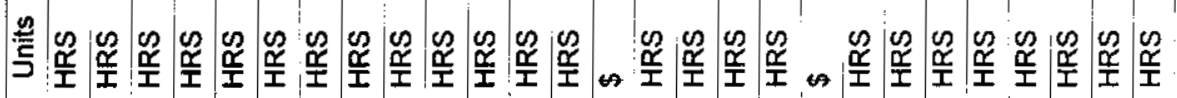
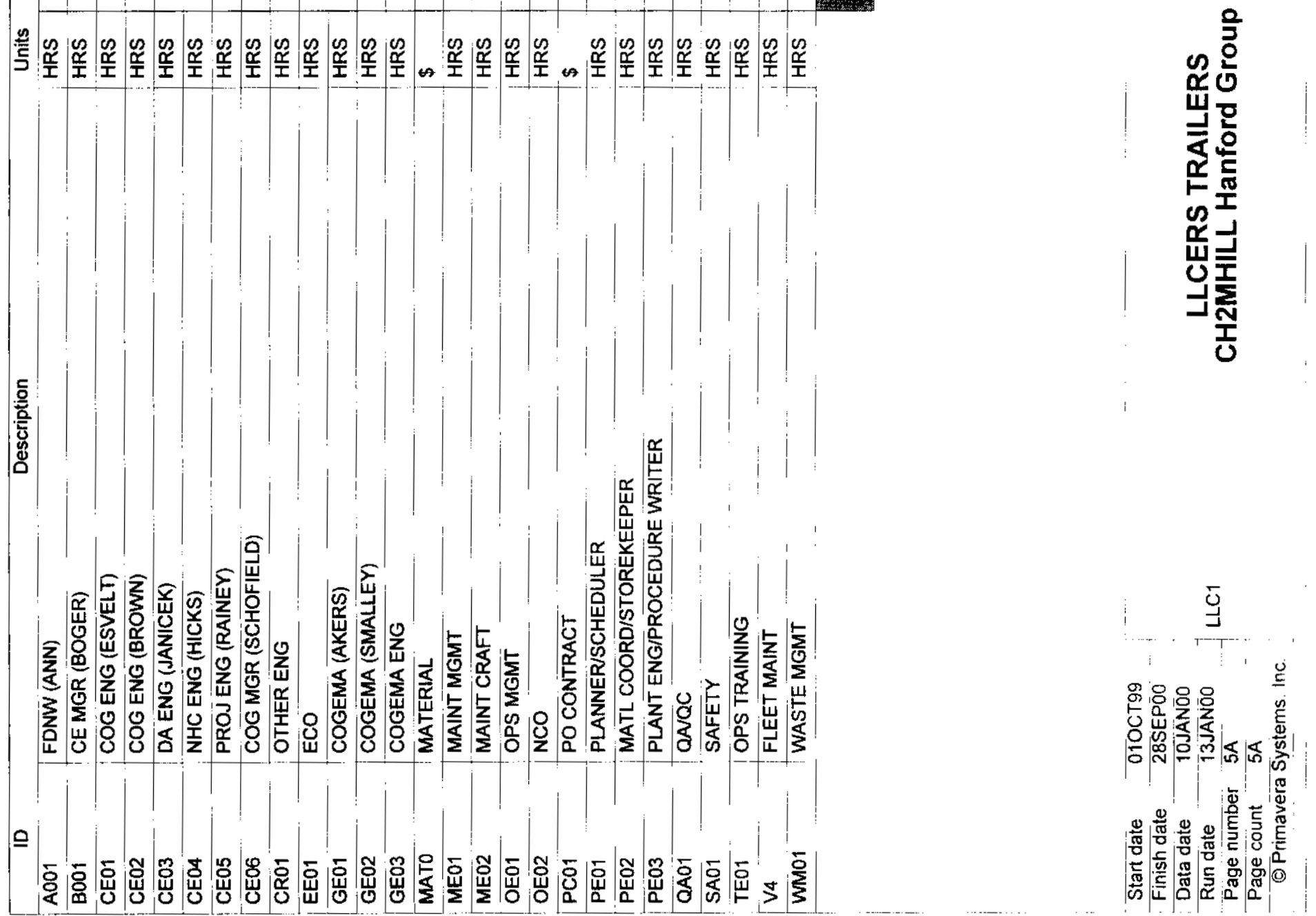
RPP-5684, REV. 0
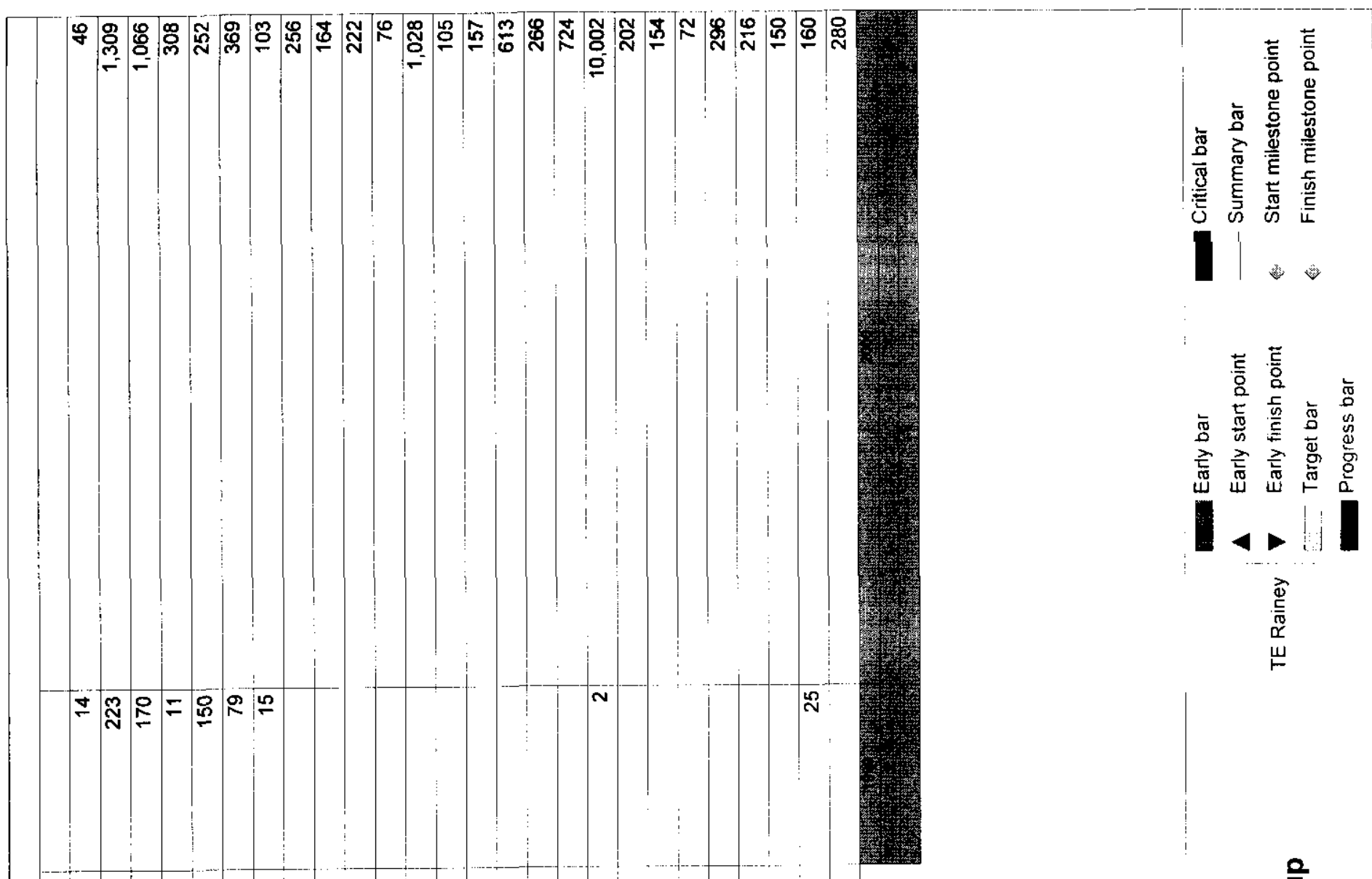

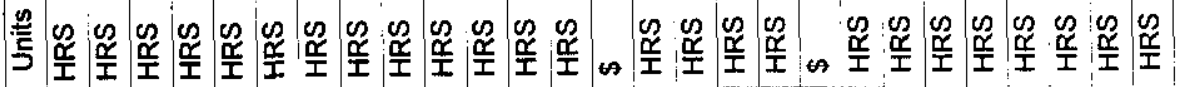

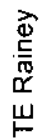

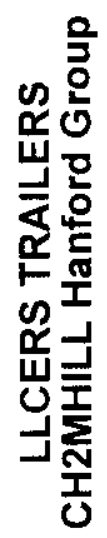

들

疍:

ż

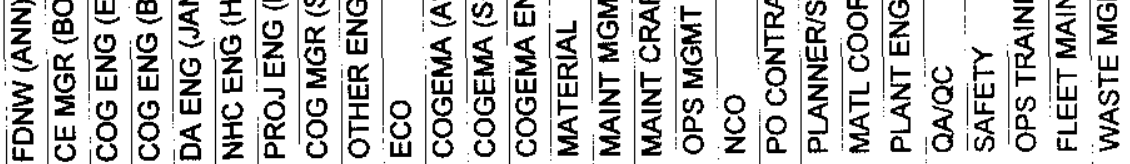

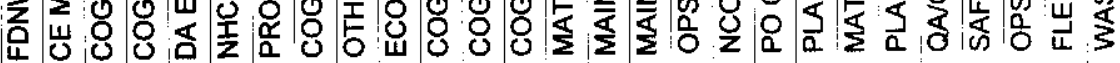

은

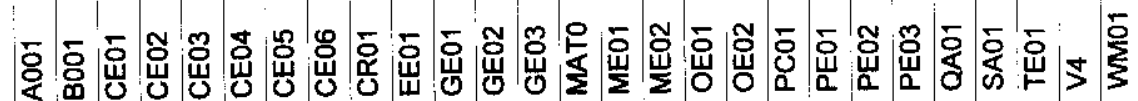

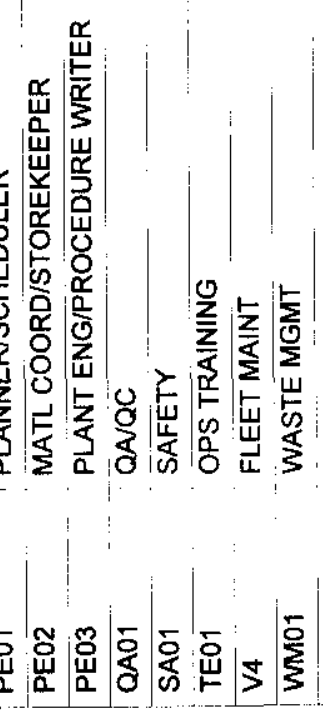

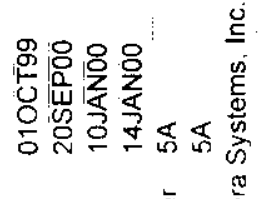

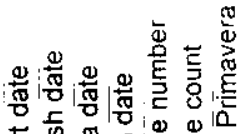

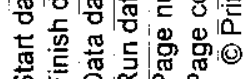

ఏ 
DISTRIBUTION SHEET

\begin{tabular}{l|l|ll}
\hline To & From & Page & I of 1 \\
\cline { 3 - 3 } Distribution & Characterization Engineering & Date $4 / 4 / 2000$ \\
\hline Project Title/Work Order & EDT No. 617987 \\
\cline { 3 - 3 } $110337 /$ LMSI Contr 4851, Re1. 33 & ECN No. N/A \\
\hline
\end{tabular}

\begin{tabular}{c|c|c|c|c|c}
\hline Name & MSIN & $\begin{array}{c}\text { Text } \\
\text { With } \\
\text { All } \\
\text { Attach. }\end{array}$ & $\begin{array}{c}\text { Text } \\
\text { Only }\end{array}$ & $\begin{array}{c}\text { Attach./ } \\
\text { Appendix } \\
\text { Only }\end{array}$ & $\begin{array}{c}\text { EDT/ECN } \\
\text { Only }\end{array}$ \\
\hline
\end{tabular}

Akers, Jeff $C$.

Allison, John E.

Bailey, Douglas M.

Bender, Tim C.

Boger, Mike

Bounini, Larbi

Brown, Rol and $G$.

Carey, Jim W.

Connolly, Rhonda R.

Criddle, Jim D.

Davis, Albert I.

Debban, Bruce L.

Dodd, Ryan A.

Ellefson, Mark D.

Esvelt, Chad A.

Ha11, Mark $N$.

Hebdon, Joel $B$.

Hicks, Dale F.

Jackson, Cary D.

Janicek, George P.

Josephson, Walter S.

Legare, Don $E$.

Mattichak, Ron W.

McCal1, Dennis L.

Miller, Phillip C.

Nester, Dean E.

Penn, Lucinda L.

Reeves, John A.

Riley, Donald L.

McElroy, Mike L.

Schofield, John S.

Shoemake, Billy J.

Sickels, Jim $F$.

Smith, Willy N.

Sparks, Jon S.

Triner, Glen C.

Troyer, Gary L.

Wolfe, Steve D.
S7-12

R3-72

R2-84

R2-84

S7-12

G1-32

S7-12

R2-82

T3-04

S7-12

T4-52

S7-90

R3 -72

T3-05

S7-12

S7-12

S6-15

S7-24

S7-34

S7-12

H1-11

R3-25

S7-12

H1-11

R1-51

T4-05

S7-03

H1-11

$\mathrm{Hl}-11$

S7-07

S7-12

S8-10

S7-03

T4-04

S7-07

T3-05

T6-50

H1-11 $x$
$x$
$x$
$x$
$x$
$x$
$x$
$x$
$x$
$x$
$x$
$x$
$x$
$x$
$x$
$x$
$x$
$x$
$x$
$x$
$x$
$x$
$x$
$x$
$x$
$x$
$x$
$x$
$x$
$x$
$x$
$x$
$x$
$x$
$x$
$x$
$x$
$x$
$x$
$x$
$x$

$x$ 